\title{
futures
}

\section{A pocket full of phlogiston}

\author{
Memories are made of this.
}

$\mathrm{D}$ mitri's ship hovered above the Moon, its impetus spent. Like attracts like as Aristotle once said - so lunar quintessence exerted no pull on his iron ship, so he hovered. Dmitri did not miss gravity, but the stillness of the aether worried him. If his engines failed, the Lunar Sphere contained no external force to nudge him Earthward.

More than anything, except for Svetlana and little Sasha, he missed momentum. Once, his own passion had driven him, but now he worked off his indenture to the Astrologer.

Dmitri missed the Moon, too - not the defaced cue-ball in his viewscreen but the cratered one that had entranced Svetlana when they had lain on the grass and watched the night sky. He reached out with withered hands and activated the harvester. He winced. Sympathetic pain shot through the scarred skin of his palms and fingertips as the device carved another scar into the lunar surface.

The words of the Astrologer echoed in the back of his mind.

"Your world is nothing but ash. You work for me now."

"Who will notice?" the Astrologer had asked, a few days before launch, when Dmitri had questioned the wisdom of mining the Celestial Spheres. "The gods and titans quarried the Moon long ago. Why not us?"

Why not?

Dmitri wished he had asked himself that question. Back home, he had built a bridge between realities and revived - or perhaps discovered - an ancient physics, steeped in sulphur and mercury. He had buried himself in dusty tomes and sifted through esoteric recipes until he had put the old sages to shame. In that final moment, he had held the philosopher's stone in his hands. An instant later it had burst into flames, and even then it had not occurred to him to ask... why not?

A charred photograph, nailed to the hylomorphic scanner's display panel, now served as a reminder. Svetlana and Sasha were black silhouettes against grey. The edges had crumbled. The shape of Svetlana's hair and the curve of her shoulders gave him enough

NATURE.COM

Follow Futures: y @NatureFutures f go.nature.com/ mtoodm him — dazed and smouldering — on an electrum launch pad. The Astrologer had appropriated Dmitri's wedding ring — gold is gold in any reality - and tossed the picture of Svetlana and Sasha onto the dirt along with Dmitri's melted stack of credit cards.

"I don't work for you," muttered Dmitri as he gunned the caloric engines and set a course for the Sun. "I work for them."

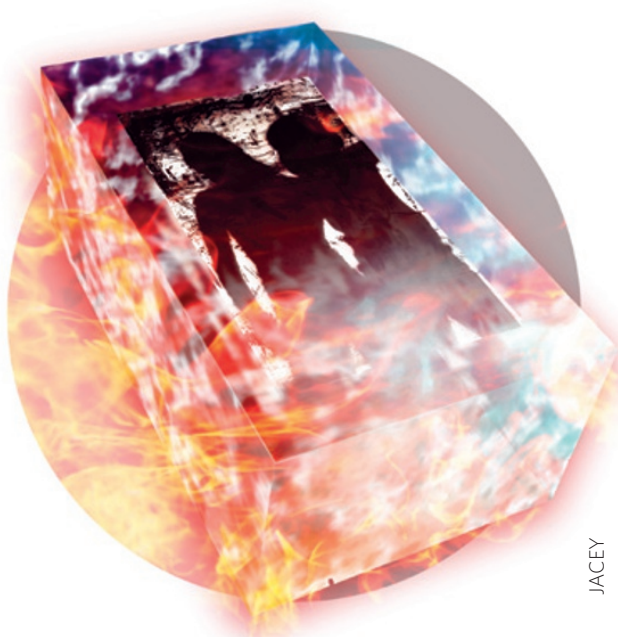

The Astrologer had no need for the Moon's quintessence, and was not fool enough to try to bring it down from the heavens. $\mathrm{He}$ believed, however, that the Sun burned with elemental fire. Harvested quintessence would shield Dmitri against the Sun's fury long enough to carve out a piece of that fire and bring it back to Earth.

Dmitri tacked into the solar wind. The hylomorphic scanners picked up caloric shot through with plumes of phlogiston.

Phlogiston. Quencher of fire. Dmitri welcomed it like an old friend. Back on Earth, ladies were eager for phlogisticated skin creams. Firefighters waited to replenish their stocks of the miracle weapon. With a cargo hold full of phlogiston, the Astrologer would go easy on Dmitri for a few weeks until the profits tapered off. Dmitri hoped it would be long enough for him to rebuild the bridge and go home.

Dmitri aimed for a plume and covered his nose and mouth with a filter that protected his lungs from phlogistonbefouled air while allowing him to exhale the phlogiston that built up in his lungs.

Dmitri missed breathing oxygen, even though phlogiston metabolism was more convenient for space travel. Oxygen burned. Sometimes it exploded. Phlogiston smothered and choked. It exuded from places where energy had once been.

Working by rote, Dmitri opened a hatch behind the cockpit and connected it to a long rubber hose. Phlogiston flowed through. At the other end of the hose, a compressor turned it into a solid brick. Dmitri carried each new brick to the back of the ship and stacked it with the others.

Phlogiston vapours flowed over Dmitri's skin, easing the pain of his burns. He wished he could force the phlogiston back into the scar tissue until the scars reverted to their original state, but phlogiston snuffed out cellular metabolism as easily as it extinguished fires. Dmitri would need a healer for that sort of therapy, and the Astrologer would keep him from seeing one, out of spite.

Dmitri had nearly filled the cargo hold before he hit upon an idea. He placed the picture face up on the floor of the compression chamber and shut the door. At the end of the compression cycle, he removed the brick and peeled the photo from its underside.

The edges of the picture were incomplete, seemingly melted, where the ash had crumbled away. Aside from that, no traces of fire remained. Ashen specks - now rephlogisticated - had become yellow, magenta, cyan; the colour of flushed cheeks; and hair in winter sunlight. Dmitri no longer strained to remember Svetlana's face.

The brick slipped from Dmitri's hand. Phlogiston poured from his lungs as he gasped for breath. So many details, he thought. How could I have forgotten?

The caloric engines sputtered. Solar fire imparted its impetus to Dmitri's ship, pushing it past the Venusian, Mercurial and Lunar Spheres.

Earth attracts earth. Dmitri gained speed. Malice attracts malice, as the Astrologer would discover soon enough. Passion attracts passion. Dmitri looked down at the picture and thought of home.

Dmitri savoured the feeling of movement. It felt like momentum.

\section{S. R. ALGERNON studied fiction writing} and biology, among other things, at the University of North Carolina at Chapel Hill. He currently lives in Singapore. 